\title{
Are subspecies (of Eira barbara) real?
}

\author{
Mauro Ignacio Schiaffini* \\ CIEMEP, Centro de Investigación Esquel de Montaña y Estepa Patagónica (Universidad Nacional de la Patagonia San Juan \\ Bosco- Consejo Nacional de Investigaciones Científicas y Técnicas), LIEB, Laboratorio de Investigaciones en Evolución y \\ Biodiversidad. Facultad de Ciencias Naturales y Ciencias de la Salud, Universidad Nacional de la Patagonia San Juan Bosco, \\ sede Esquel. Roca 780, Esquel, Chubut, Argentina
}

*Correspondent: mschiaffini@hotmail.com

The subspecies concept is one of the most controversial in Linnean taxonomy. In the past, subspecies were described without a clear conceptual framework, triggering confusion and motivating criticism of the very concept of a subspecies. At present, subspecies are conceived as aggregates of populations that are geographically isolated, are composed of interfertile individuals, and are morphologically diagnosable. The tayra, Eira barbara, was described in 1758 and has had a stable taxonomic history at the species level. However, below the species level, 16 subspecies have been named, with from two to seven subspecies recognized as valid by different authors. None of the subspecies were, however, described within a clear conceptual framework. Using the modern concept of a subspecies, I analyzed subspecies of E. barbara recognized by recent authors. I gathered morphometric data from 155 specimens in mammal collections, georeferenced each specimen, and recorded membership to subspecies assigned by different references and by its location. I gathered climate and geographic data for each location. I analyzed data using Principal Components Analysis (PCA) and analysis of variance (ANOVA). Specimens exhibited sexual dimorphism in size but not in skull shape. I used regression analysis to test for associations between skull shape and size and climate data. Geographic analyses documented that subspecies are not allopatric, violating one of the main properties of the subspecies concept. ANOVA showed significant differences in skull morphology between some pairs of recognized subspecies but not others. However, none of the subspecies segregated in the PCA. Thus, the recognized subspecies could not be diagnosed from morphological data, violating another property of the subspecies concept. Size varied greatly between the sexes using different schemes for recognized subspecies. Climate variables explained between $4 \%$ and $6 \%$ of size variation for males and females. Skull shape proved not to be geographically variable.

Key words: geographic variation, geometric morphometrics, Mustelidae, sexual dimorphism, taxonomy

El concepto de la subespecie es uno de los más controversiales en la taxonomía Linneana. En el pasado, las subespecies eran descritas sin un marco conceptual claro, generando confusión y motivando críticas al concepto per se. Actualmente, son concebidas como agregados de poblaciones que están aisladas geográficamente, compuestas de individuos interfértiles, y diagnosticables morfológicamente. La tayra Eira barbara fue descrita en 1758 y tiene una historia taxonómica estable a nivel de especie. Sin embargo, a un nivel taxonómico inferior, 16 subespecies han sido descritas, y distintos autores proponen la existencia de a partir de dos hasta tantas como siete subespecies válidas. Sin embargo, ninguna de las subespecies fue descrita bajo un marco conceptual claro. Usando el concepto actual, analizé las subespecies de E. barbara reconocidas por diferentes autores. Tomé datos morfométricos de 155 especímenes depositados en colecciones de mamíferos, georreferenciando cada uno y asignándole su pertenencia a una subespecie según referencias y procedencia geográfica. Tomé datos sobre clima y geografía para cada localidad. Llevé a cabo Análisis de Componentes Principales (ACP) y Análisis de Varianza (ANOVA). Observé dimorfismo sexual en el tamaño, pero no en la forma del cráneo. Usé Análisis de Regresión para estudiar la asociación entre forma y tamaño con información climática. El análisis geográfico indicó que las subespecies no son alopátricas, violando una de las principales propiedades del concepto de subespecie.

(C) The Author(s) 2020. Published by Oxford University Press on behalf of the American Society of Mammalogists, www.mammalogy.org. 
El análisis de ANOVA mostró diferencias significativas en la morfología del cráneo entre algunos pares de subespecies, pero no entre otros. Sin embargo, ninguna de las subespecies se segregó en los ACP. Por lo tanto, no pudieron ser diagnosticadas morfológicamente, violando así otra propiedad del concepto de subespecie. El tamaño entre sexos varió en gran medida bajo distintos esquemas de subespecies reconocidas. Las variables climáticas explicaron entre 4 y $6 \%$ de la variación de tamaño en machos y hembras. La forma del cráneo resultó no ser variable geográficamente.

Palabras clave: dimorfismo sexual, morfometría geométrica, Mustelidae, taxonomía, variación geográfica

No taxonomic rank has been more challenged and found more confusing than the Linnean rank of subspecies, except perhaps the species rank itself. A long-lasting debate about the subspecies concept started in the mid-20th century (Mayr 1942, 1954; Amadon 1949; Wilson and Brown 1953; Gosline 1954). Wilson and Brown (1953) criticized the concept as being the most "disorderly area of modern systematic theory." They noted that subspecies had been defined using characters that showed independent geographic variation, leading to polytypic subspecies, microgeographical subspecies, and arbitrary lower limits for subspecies. They proposed that subspecies be dropped altogether and be replaced by simple descriptions of localities (Wilson and Brown 1953; see also Gosline 1954; Gilham 1956). Burbrink et al. (2000) and Zink (2004) criticized the subspecies concept for treating subspecies as early evolutionary stages of speciation, or as being "incipient species" (Mayr 1942). Thus, to assign a subspecies would require unobtainable knowledge of the future and, hence, would not be scientific because such knowledge can not be tested. Nonetheless, the original subspecies concept of Mayr (1942) referred to geographic variation in allopatric populations and was not a concept of evolutionary biology (Mayr 1982). In addition, even if subspeciation were considered to be a stage in allopatric speciation, not all subspecies need become species (Patten 2010). Zink (2004) criticized the subspecies concept further because considering subspecies to be evolutionary units can lead to the misuse of the limited funds available for conservation and for protecting biodiversity.

Several concrete definitions have been developed for subspecies, such as "subspecies are geographically defined aggregates of local populations which differ taxonomically from other such subdivisions of the species" (Mayr et al. 1953; O'Brien and Mayr 1991) and a subspecies is "a collection of populations occupying a distinct breeding range and diagnosably distinct from other such populations" (Patten 2015). The crucial properties of a subspecies are hidden in plain sight within these definitions. Subspecies can be defined as members of a species that by definition are 1) everywhere interfertile, 2) demonstrate geographic variation, and 3) are diagnostically distinct groups of populations in regions that are geographically distinct (Haig et al. 2006; Patten 2010). Geographical variation should be evidence of adaptive responses to distinct geographical conditions (Mayr 1982; Mayr and Ashlock 1991). Related to these properties, the fate of a subspecies may include extinction, appearance of new subspecies by genetic drift and selection, or the appearance of new species by acquisition of genetic isolating mechanism (see O’Brien and Mayr 1991).
A major and often neglected point is that if no geographical isolation exists or what variation exists is clinal, then subspecies cannot be defined (Patten 2010). Under these conditions, the number of arbitrary subdivisions is unlimited and the usefulness of subspecies decreases when subspecies are described on the basis of distinctions that are not geographic or are too slight to separate populations (Amadon 1949). Because geographical variation can range from subtle to quite large, geographical distinction must be arbitrary. The "75\% rule" of Amadon (1949) states that subspecies A is valid only if $75 \%$ of its members can be distinguished from $99 \%$ of subspecies $\mathrm{B}$ individuals and that the reverse is also true. Recent advances in taxonomy using variation in mitochondrial and nuclear DNA allow for countless subspecific delimitations, depending on the study scale. Thus, genetic variation must be used together with morphological variation (Haig et al. 2006; Patten 2015).

That members of different subspecies must be interfertile is critically important because the subspecies concept is defined within the biological species concept (Patten 2010). Different subspecies must consist of populations occupying different geographic regions, but must not be reproductively isolated: if groups of populations occupy distinct geographic ranges and are reproductively isolated, then they are not subspecies.

Some important studies analyzed subspecies concept and its use in mammals (Gippoliti and Amori 2007), mainly in Primates (Stanford 2001; Groves 2012), but not much such work has been carried out on South American mammals. Larivière and Jennings (2009), as well as the IUCN Red List (www.iucnredlist.org) list 45 species of extant terrestrial South American carnivorans (Mammalia: Carnivora) with 152 recognized subspecies inhabiting strictly South America. If one adds subspecies from outside South America for the 45 species, the number increases to 262 subspecies. The extreme case is Mustela frenata Lichtenstein 1831 with 42 recognized subspecies (Larivière and Jennings 2009). Of the 45 South American species, $10(22 \%)$ are "threatened" (IUCN Vulnerable or Endangered) and 11 (25\%) Near Threatened. As a result of the foregoing, a detailed analysis is badly needed of the subspecies status of South American carnivorans (and undoubtedly all South American mammals) within the present conceptual framework for subspecies. Here I provide such an evaluation for the subspecies of Eira barbara, the tayra, as an example.

\section{A case study: subspecies of Eira barbara (Linnaeus 1758), the} tayra

Of the 45 extant, terrestrial carnivoran species in South America, 12 are mustelids (Carnivora: Mustelidae), distributed among 
seven genera and four subfamilies: 1) Ictonychinae Pocock 1922, including Galictis Bell 1826 and Lyncodon Gervais 1844; 2) Lutrinae Bonaparte 1838, including Lontra Gray 1843 and Pteronura Gray 1837; 3) Mustelinae Fischer 1817, including Mustela Linnaeus 1758 and Neovison Baryshnikov and Abramov 1997 (introduced); and 4) Guloninae Gray 1825, including Eira Smith 1842. The Guloninae is mainly a Holartic subfamily, with Eira barbara being the only South American representative (Koepfli et al. 2008; Yu et al. 2011; Sato et al. 2012; Wolsan and Sotnikova 2013; Li et al. 2014; Ercoli and Youlatos 2016). Eira barbara is a large ( $\leq 7 \mathrm{~kg})$, omnivorous mustelid, present from southern Mexico to northern Argentina, that inhabits tropical and subtropical forests (Emmons and Freer 1990; Presley 2000; Schiaffini et al. 2017).

The genus Eira currently is recognized as monotypic, including only Eira barbara (Linnaeus 1758). Smith (1842), however, also presented three other species of the genus: Eira ilya "of Markgrave," which was synonymized with E. barbara by Thomas (1900; see also Allen 1904); Eira galera; about which Smith stated "... is in form so like the first (E. barbara), that it may still be only a variety of colour..."; and Eira ferruginea, a particularly confounding case. The latter originally was described as a "ferrugineous glutton" Gulo castaneus Griffith 1827 based on a scientific illustration from a specimen of Bullock's Museum. Years later, Smith (1842) examined the same figure, suggesting it instead belonged to another genus (Gulo), while temporarily retaining it in Eira, as E. ferruginea. Smith added that because he had not "been able to examine the dentition of this species, it may still prove distinct from this genus [N.B.: Eira]" (Smith 1842:204), and instead was an African representative of Gulo, G. castaneus. According to Smith it was "... an aberrant Eira, assuming more the livery of a glutton...." Plate XVI in Smith (1842) indicates "native of Africa" which might be due to an error in the provenance of the specimen, confounding Guiana with Guinea (Smith 1842). Eira ferruginea now is considered to be synonym of $E$. barbara.

The taxonomic history of E. barbara has been stable at the species level since its original description as Mustela barbara (Linnaeus 1758); however, 16 subspecies have been named based on body size and pelage coloration: 1) Mustela barbara barbara (= E. b. barbara; Linnaeus 1758); 2) Mustela sinuensis (= E. b. sinuensis, Humboldt 1812); 3) Viverra poliocephalus (E. b. poliocephala, Traill 1821); 4) Tayra barbara bimaculata (= E. b. bimaculata, Martínez 1873); 5) Galictis barbara peruana (= E. b. peruana, Nehring 1886); 6) Galictis barbara senex (= E. b. senex, Thomas 1900); 7) Galictis barbara biologiae (= E. b. biologiae, Thomas 1900); 8) Galictis barbara trinitatis (= E. b. trinitatis, Thomas 1900); 9) Galera barbara brunnea (= E. b. brunnea, Thomas 1901); 10) Tayra barbara irara $(=$ E. b. irara, Allen 1904); 11) Tayrabarbarainserta $(=$ E. b. inserta, Allen 1908); 12) Tayra barbara senilis (=E. b. senilis, Allen 1913); 13) Tayra barbara tucumana (= E. b. tucumana, Lönnberg 1913); 14) Tayra barbara madeirensis (= E. b. madeirensis, Lönnberg 1913); 15) Tayra barbara gulina (= E. b. gulina, Allen 1916); and 16) Tayra barbara kriegi (= E. b. kriegi, Krumbiegel 1942).
In his treatise on South American mammals, Cabrera (1958) synonymized all South American representatives of E. barbara into five subspecies: E. b. barbara, from "eastern and southern Brazil to Mato Grosso, Paraguay, and northern Argentina to Tucuman"; E. b. sinuensis, from "Colombia, western Venezuela and western Ecuador, extending also to the north through Panama, to Costa Rica"; E. b. poliocephala, from "low Amazonia, Guianas and eastern Venezuela"; $E . b$ peruana, from "Peru, east of the central Andes, and western Bolivia"; and E. b. madeirensis, from "western Brazil, eastern Ecuador and northeastern Peru." He also indicated that Galictis barbara var. peruana Tschudi 1844 was a nomen nudum; hence, the subspecies $E$. $b$. peruana corresponded to the name used by Nehring (1886). Cabrera (1958) did not address the subspecies exclusively inhabiting Central America: E. b. senex, E. b. trinitatis, and E. b inserta. Presley (2000) recognized the five South American subspecies recognized by Cabrera (1958) plus E. b. senex and E. b. inserta; he did not address $E$. b. trinitatis. That author added a map showing the range of each subspecies. The most complete taxonomic revisions, by Wozencraft (2005) and Larivière and Jennings (2009), followed Presley's scheme. Hereafter, I refer to Presley's scheme of seven subspecies as the "Size and Pelage" scheme, because the subspecies were originally described on the basis of body size and pelage colors and patterns.

Using mtDNA (Cyt-b and NADH-5) to analyze putative South American subspecies (excluding Central American subspecies) of E. barbara, Ruiz-García et al. (2013) synonymized E. b. sinuensis, E. b. peruana, and E. b. madeirensis, with E. b. barbara, but retained E. b. poliocephala from French Guyana. A few years later, also using mtDNA (NADH-5) and including the Central American E. b. inserta, distributed from southern Guatemala to southern Costa Rica, Mejía Young (2018) synonymized all South American subspecies with E. b. barbara, but retained E. b. inserta. Hereafter, I refer to the subspecies scheme of Ruiz-García as the "mtDNA" scheme. It should be kept in mind, however, that subspecies do not necessarily need to be monophyletic regarding mitochondrial genes (Patten 2010; Braby et al. 2012) and that characters and populations respond differentially to evolutionary processes: "the formal recognition of subspecies should focus on both the documentation and assessment of this almost inevitable discordance, not on the rigid adherence to a molecular-only view of history" (Patton and Conroy 2017). As a result, the scheme of Ruiz-García et al. (2013) will be analyzed (see below) even if does not adhere strictly to a subspecies concept.

Clearly, confusing definitions and delimitations of subspecies plague the taxonomic history of Eira barbara. Using geometric morphometric analysis of skulls collected from throughout the range of E. barbara, I address the following questions: 1) Do morphological traits of E. barbara exhibit geographic variation? and 2) Do any of the recognized subspecies of E. barbara meet the requirements for designating subspecies? 


\section{Materials ANd Methods}

\section{Data acquisition}

I recorded morphometric data for skulls from individuals of E. barbara across the entire species' range from central Mexico to northern Argentina (Presley 2000; Larivière and Jennings 2009; Schiaffini et al. 2017). This range includes parts both of the Nearctic and Neotropical realms and includes several different ecoregions (Dinerstein et al. 2017). Within its range, E. barbara has a marked preference for forested environments (Schiaffini et al. 2017).

I examined 155 specimens held in museums (see Appendix 1 for complete list of specimens examined). I included only adult specimens (completely erupted dentition and basioccipitalbasisphenoid sutures not visible; Van Gelder 1968) with well documented geographic locations. I excluded specimens from zoological parks.

\section{Morphometric data}

I took digital photographs of every skull in ventral view and mandible in lateral view. I oriented specimens parallel to the photographic plane, with the camera set on a tripod and oriented with a "bullseye" level. I took all photographs using the same camera (Sony $\alpha 58$ with 16-105 mm lens; Sony Corporation, Tokyo, Japan). I placed semilandmarks consistently using MakeFan6 software (Sheets 2002) and digitized with TPSDig 2.31 (Rohlf 2017). I carried out Generalized Procrustes Analysis (GPA-Goodall 1991; Rohlf 1999) using the "geomorph" 3.1.0 package (Adams et al. 2019) in R 3.5.1 (R Core Development Team 2018). I used Centroid Size as my measure of specimen size (see Zelditch et al. 2004). I used 48 landmarks on the skulls and 36 on the mandibles (Supplementary Data SD2).

I analyzed morphometric data using Principal Components Analysis (PCA) in the geomorph package (Adams et al. 2019) and Analysis of Variance (ANOVA) in the RRPP package 0.4.0.9000 (Collyer and Adams 2018, 2019). PCA is used widely (Jolliffe 2002), while residual randomization in permutation procedures (RRPP) has proved to be useful for high-dimensional data, such as Procrustes coordinates, and can handle both large $p: n$ and $n: p$ ratios (with $p=$ number of landmarks and $n=$ number of individuals; Collyer et al. 2015; Collyer and Adams 2018). To accommodate the differences in mean skull shape among groups (Remsen 2010) and the Procrustes variances between them, I analyzed morphological disparity using the package geomorph (Adams et al. 2019).

I visualized size data with box-plots and analyzed differences among putative subspecies using ANOVA. Normality of distribution was tested using the Shapiro-Wilks test, and homocedasticity tested with Non-constant error variance using the package "car" (Fox and Weisberg 2011) in R. I used crossvalidation tables to analyze the overlap of sizes among different subspecies in the different taxonomic schemes (Marantz and Patten 2010). Because most mustelids studied, and all mustelids within the subfamilies Guloninae and Mustelinae, exhibit sexual dimorphism (Moors 1980; Dayan and Simberloff
1994), I used ANOVA to test for differences in skull size and shape between sexes. Males were significantly larger than female $(F=149.92, P<0.01)$, and shape likewise differed between sexes $(F=4.762, P<0.01)$. I tested for allometry using geomorph (Adams et al. 2019) with 999 permutations. Size explained $2.5 \%$ of shape variation $(F=1.88, P<0.05)$ among males. Large specimens had wide palates, short snouts, robust and round zygomatic arches, and short basicrania. Allometry was not significant for females $(F=1.34, P=0.141)$. Males not only were larger but also more variable in size than females: Coefficient of Variation (Yablokov 1974) of log-centroid size was 4.42 for males and 3.96 for females.

Because allometry was significant, I re-analyzed shape sexual dimorphism using centroid size as a covariable (i.e., to include allometric changes), yielding different results. Shape no longer differed between sexes $(F=1.192, P=0.251)$. For all subsequent analyses of size, I split the dataset in two by sex and carried out shape analyses for females and males together including size as a covariable.

I tested for morphological integration using both skull and mandible datasets using the package geomorph (Adams et al. 2019 ) in R. I present results only for skulls because morphological integration reached $65 \%$ with low $P$-values $(<0.01)$ between datasets.

\section{Schemes of subspecies analyzed}

I analyzed skull size and shape using three different schemes for subspecies:

1) Size and Pelage, following Presley (2000), after Cabrera (1958) and Hall (1981). This scheme recognizes seven subspecies: E. b. barbara, E. b. sinuensis, E. b. poliocephala, E. b. madeirensis, E. b. peruana, E. b. inserta, and E. b. senex (Fig. 1A).

2) mtDNA, following Ruiz-García et al. (2013). These authors analyzed South American specimens only. To make this scheme cover the same geographic area as the other two, I included the two Central American subspecies recognized by Presley (2000), such that this scheme has four subspecies: E. b. barbara, E. b. poliocephala, E. b. inserta, and E. b. senex.

3) I developed a new scheme extracted directly from the geographical location for each specimen, following the proposal of Wilson and Brown (1953). I calculated a minimum spanning tree for the localities and used it to infer membership in geographic regions. Each location is connected to its nearest neighbor so as to minimize the total length of the tree (Morrone and Crisci 1995). I identified three groups of specimens: 1) Central American specimens; 2) northern South American specimens; and 3) remaining South American specimens (Fig. 1B). Hereafter, I refer to this scheme as the "Geographical Provenance" subspecies scheme.

I georeferenced localities of all specimens (Fig. 1B). The membership of each specimen to a subspecies was assigned using Presley’s (2000) map (redrawn as Fig. 1A). 


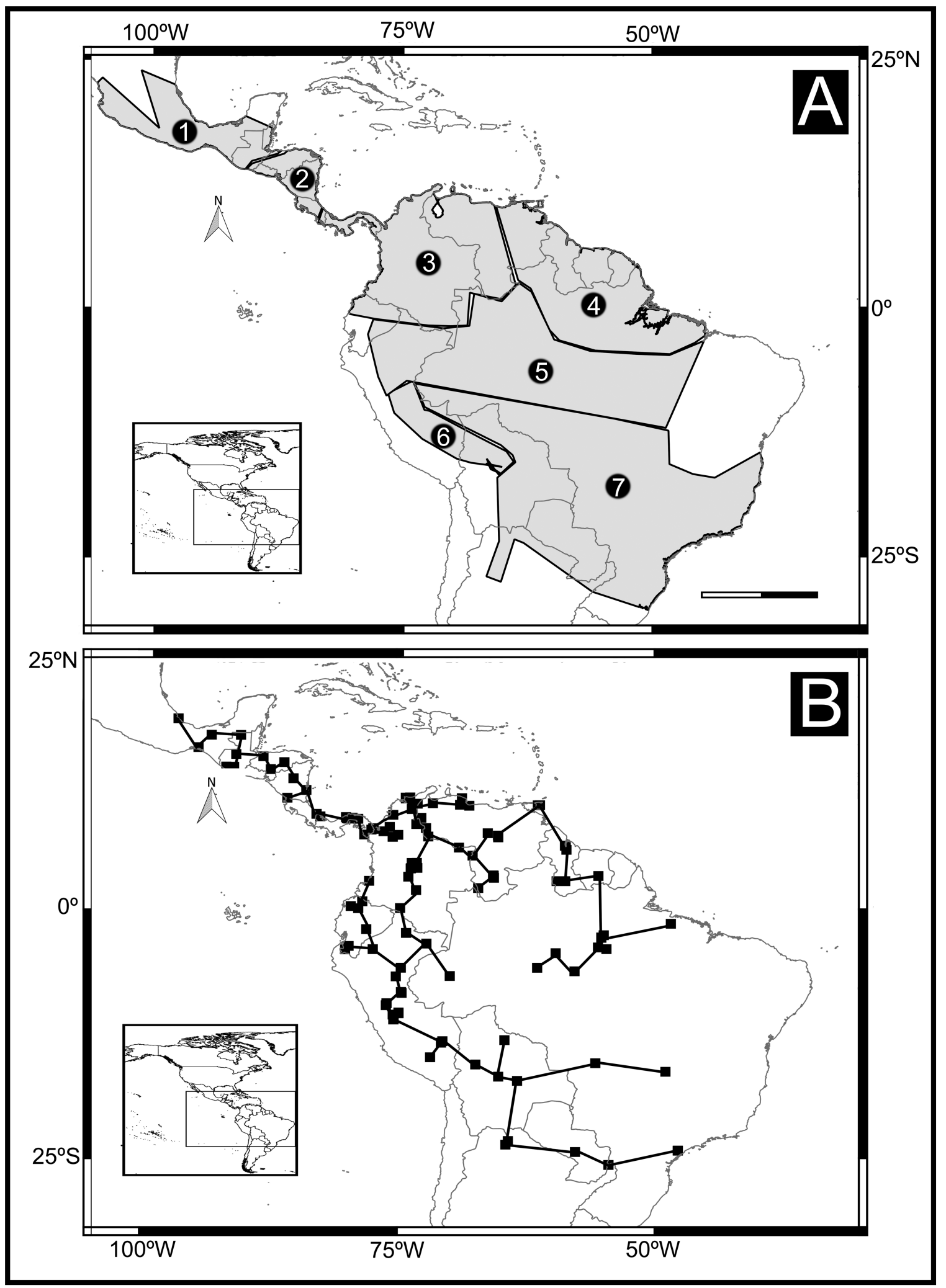

Fig. 1.- Recorded localities for Eira barbara (A) and minimum spanning tree (B). Commonly known subspecies according to Presley (2000). Scale (black and white bar): $1000 \mathrm{~km}$.

\section{Geographic variation and environmental conditions}

To describe the environmental conditions at the location of each specimen, I assigned climate and ecological variables: mean annual temperature, mean diurnal temperature range, isothermality, annual precipitation, seasonality of precipitation (Hijmans et al. 2005), net primary productivity (Npp-Foley 
et al. 1996; Kucharik et al. 2000), potential evapotranspiration (PET-Willmott and Matsuura 2001), and the Enhanced Vegetation Index (EVI-downloaded from www.daac.ornl. gov). To analyze the data for multicollinearity (Dormann et al. 2013) and run pair-wise correlations (i.e., $r<0.7$ ), I logtransformed these variables because they are expressed in different units.

I analyzed spatial autocorrelation (Kissling and Carl 2007; Diniz-Filho et al. 2008; Hawkins 2008) using correlograms based on Moran's I coefficient in SAM 4.0 (Rangel et al. 2010). If I detected spatial autocorrelation, I used Spatial Eigenvector Mapping, incorporating spatial predictors into subsequent analyses (obtained from eigenvector analysis of a distance matrix-Diniz-Filho and Bini 2005).

I analyzed geographic variation of skull size with ordinary least-square regression (OLS) between centroid size and each environmental variable in SAM (Rangel et al. 2010). I analyzed the degree of spatial autocorrelation in residuals, and if necessary, repeated the analyses including spatial predictors. To analyze how each variable affects the size in the presence of other predictors, I carried out multiple regression between centroid size and all predictive variables. I analyzed the degree of multicollinearity using Variance Inflation Factor (VIF-Chatterjee and Hadi 2006). For model selection based on the Akaike information criterion (AIC-Akaike 1973) and model averaging (Grueber et al. 2011), I used package MuMIn (Bartón 2019) in R.

I analyzed changes of skull shape associated with climate variables with ANOVA and used spatial filters and centroid size as covariables to analyze the influence of environmental factors independent of allometry and spatial autocorrelation (Geomorph and RRPP packages in R-Collyer and Adams 2018, 2019; Adams et al. 2019).

\section{RESUltS}

I analyzed 155 skulls (77 M, 78 F) with known geographic locations (Appendix 1). The PCA showed no clear segregation patterns for morphological variables. The first four Principal Components (PC) explained 24\%, $16 \%, 7 \%$, and $5 \%$ of the variance. Slenderness of the basicranium and straightness of the zygomatic arch mapped to PC1, with a slender basicranium and straight zygomatic arches having positive values. Anteriorly placed glenoid cavity had positive values for PC2. Elongated palates had positive values for PC3 and posteriorly placed palatal foramina had positive values for PC4 (Fig. 2).

In the analysis of morphological disparity, total Procrustes variance was higher for males (overall Procrustes variance $=0.00115822$ without including centroid size and 0.00112983 after including it) than for females (overall Procrustes variance $=0.00095967$ without including centroid size and 0.00094296 after including it).

\section{Analyses of subspecies schemes}

Size and Pelage.-The ANOVA using mean values showed significant differences between some subspecies pairs $(P<0.05$;
Table 1). Putative subspecies E. b. peruana had larger morphological disparity than did E. b. inserta and E. b. senex, but no pairs of subspecies differed for Procrustes variance (Table 1). Principal Component Analysis showed no segregation of any putative subspecies (Fig. 2A and 2B).

For male data, no pairs of subspecies differed for skull size, but female E. b. barbara were larger than both E. b. poliocephala and $E$. $b$. sinuensis. The largest specimens were males and females of $E$. $b$. inserta and E. b. barbara, while smallest were males of E. b. peruana and females of E. b. poliocephala (Fig. 3A and 3B). Cross-validation using centroid size showed high error rates for all groups, indicating males and female cannot be classified correctly using size (Table 2).

Mitochondrial DNA defined subspecies scheme.-The ANOVA found no significant differences among any putative subspecies pairs using mean values (Table 3 ). The analysis of skull shape variation using Procrustes variance found significantly larger values for morphology disparity for E. b. barbara than for $E$. b. senex $(P<0.05$; Table 3$)$. Putative subspecies did not segregate in the PCA (Fig. 2C and 2D).

Skulls of male and female $E$. $b$. inserta considered together were larger than those of E. b. poliocephala. Sizes of males' skulls did not differ among any subspecies pairs but skulls of female $E$. b. inserta were larger than those for E. b. poliocephala (Fig. 3C and 3D). Cross-validation using centroid size showed high error rates for all groups, documenting that correct classification could not be achieved using size of males and females (Table 4).

Geographical provenance.-The ANOVA found no differences in mean skull shape or Procrustes variance among the three groups (Table 5). The groups did not segregate in PCA (Fig. 2E and 2F). Skulls of males of group 1 (Central America) were significantly larger than those from groups 2 and 3 (South America; Fig. 3G). In contrast, skulls of females of groups 1 and 3 (Central and southern South America) were significantly larger than those from group 2 (northern South America; Fig. 3F). Cross-validation using centroid size showed high error rates for all groups, documenting that correct classification could not be achieved using size of males and females (Table 6).

\section{Geographic variation and environmental conditions}

Moran's I showed the presence of spatial autocorrelation for the centroid size of male skulls. After application of the third Spatial Filter into OLS, values of Moran's I were low $(<0.1)$. The only variable that described part of the size variation of male skulls was seasonality of precipitation (4.4\%, OLS, $P<0.05$; Table 7). The slope of the regression was negative, indicating that large size correlated with small values of precipitation seasonality. The model with lowest AIC included only seasonality of precipitation plus the third spatial filter, which is the same as that of OLS. Six models had a $\triangle \mathrm{AIC}<2$ (DinizFilho et al. 2008) and after model averaging, the most important variable again was precipitation seasonality, with negative slope, followed by net primary productivity, with positive slope (as the Spatial Filter was included as a fixed term in all models, its importance equals $=1$; Table 8 ). 

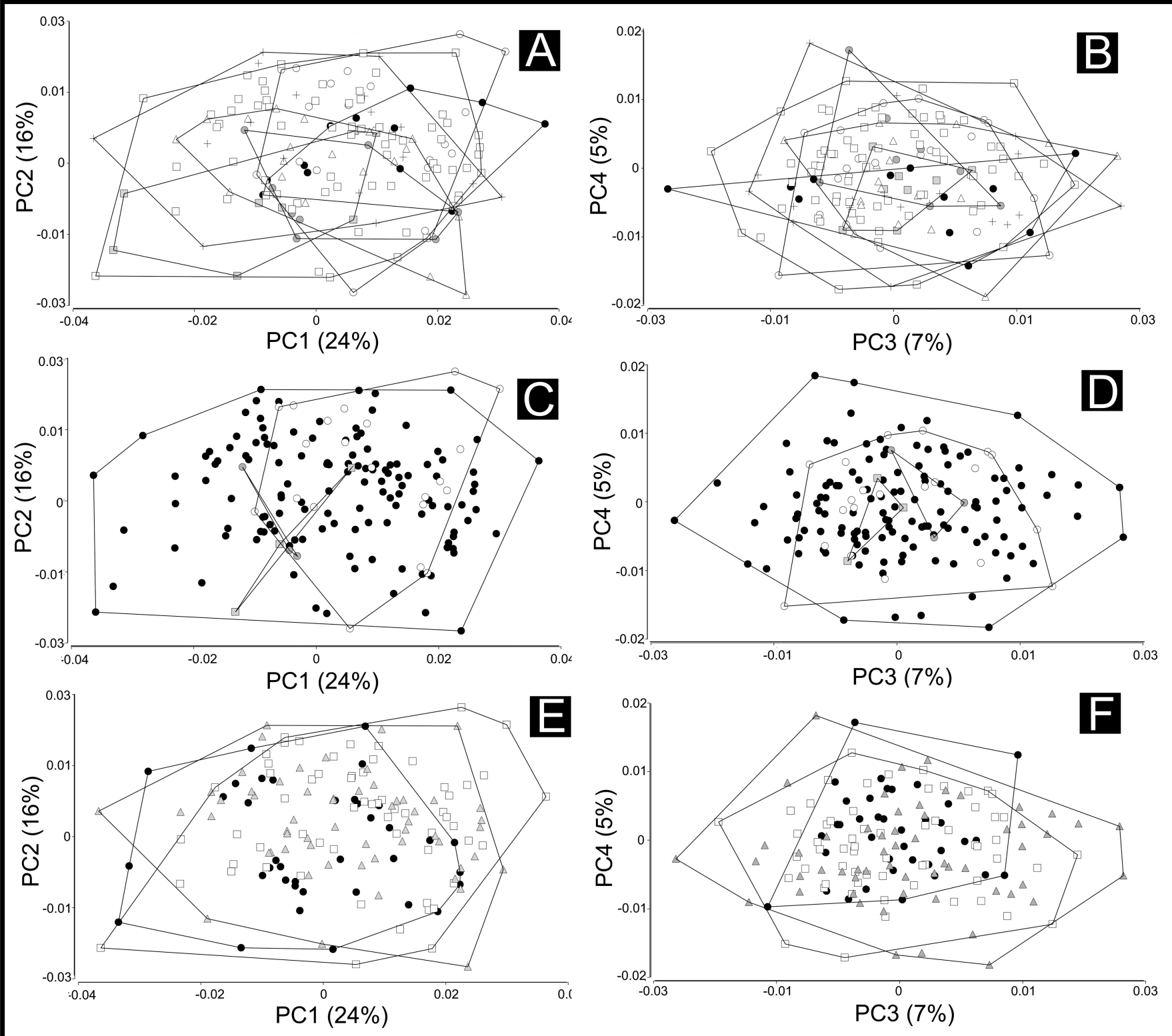

Fig. 2.- Principal Component Analysis for skull in ventral view sensu Size and Pelage scheme (A and B); sensu mitochondrial DNA scheme (C and D); and sensu geographic provenance (E and F). Polygons joining members of the same groups. Symbols for A-D: E. $b$. barbara (black circles), E. $b$. inserta (gray squares), E. b. madeirensis (white triangles), E. b. peruana (black cross), E. b. poliocephala (white circles), E. $b$. senex (gray circles), E. b. sinuensis (white squares). Symbols for E-F: "1" (black circles), "2" (white squares), "3" (gray triangles).

For females, Moran's I showed spatial autocorrelation but after application of the first Spatial Filter to OLS, Moran's I was small $(<0.1)$. Isothermality and Potential Evapotranspiration accounted for $6.5 \%$ and $4.6 \%$ of size variation (Table 7). Both had negative slopes of regression, indicating that large size correlated with low isothermality and low potential evapotranspiration. The model with lowest AIC included mean diurnal temperature range, isothermality, net primary productivity, and the first spatial filter, explaining $19 \%$ of skull size variation. Nevertheless, isothermality and net primary productivity described $4.8 \%$ and $6.1 \%$ of variation; no other variables made significant contributions to the model. After averaging the nine models with a $\triangle \mathrm{AIC}<2$, the most important variable was isothermality, with a negative slope, followed by net primary productivity, with positive slope (Table 9).

ANOVA for skull shape variation with environmental predictors using centroid size as covariable found no difference for any variable. The same results were found using all predictors together, regardless of the use or not of centroid size as covariable.

\section{Discussion}

Do the recognized subspecies of Eira barbara meet the criteria for designating subspecies?

Three main criteria must be fulfilled by populations (or groups of populations) to designate subspecies: occupy distinct 
Table 1.-Pairwise ANOVA using 1,000 iterations using mean shape and Procrustes variance of skull shape (Procrustes coordinates) and putative subspecies sensu Size and Pelage scheme. In bold, significant values at $P<0.05$.

\begin{tabular}{|c|c|c|c|c|}
\hline \multirow[b]{2}{*}{ Subspecies pairs } & \multicolumn{2}{|c|}{ Mean } & \multicolumn{2}{|c|}{$\begin{array}{c}\text { Procrustes } \\
\text { Variance }\end{array}$} \\
\hline & $Z$ & $P$-value & $Z$ & $P$-value \\
\hline E. $b$. barbara vs E. $b$. inserta & 0.6415 & 0.263 & -0.916 & 0.818 \\
\hline E. b. barbara vs E. b. madeirensis & 1.0585 & 0.154 & -1.064 & 0.875 \\
\hline E. b. barbara vs E. b. peruana & 1.8259 & 0.04 & -0.441 & 0.585 \\
\hline E. b. barbara vs & 0.7064 & 0.241 & -0.903 & 0.815 \\
\hline \multicolumn{5}{|l|}{ E. b. poliocephala } \\
\hline E. $b$. barbara vs $E$. $b$. senex & 0.5667 & 0.286 & 0.7346 & 0.216 \\
\hline E. b. barbara vs E. $b$. sinuensis & 0.5956 & 0.262 & -0.768 & 0.738 \\
\hline E. b. inserta vs E. b. madeirensis & 1.3152 & 0.1 & -0.566 & 0.651 \\
\hline E. b. inserta vs E. b. peruana & -1.031 & 0.84 & -0.036 & 0.427 \\
\hline E. b. inserta vs E. $b$. poliocephala & -0.074 & 0.534 & -1.164 & 0.948 \\
\hline E. b. inserta vs E. $b$. senex & -0.283 & 0.548 & 0.2538 & 0.325 \\
\hline E. b. inserta vs E. $b$. sinuensis & -0.96 & 0.836 & -0.368 & 0.554 \\
\hline E. $b$. madeirensis vs $E$. $b$. peruana & 2.2704 & 0.013 & -0.544 & 0.626 \\
\hline E. b. madeirensis vs & 1.4084 & 0.09 & -0.569 & 0.633 \\
\hline \multicolumn{5}{|l|}{ E. b. poliocephala } \\
\hline E. b. madeirensis vs E. $b$. & 1.1051 & 0.135 & 1.1983 & 0.137 \\
\hline E. b. madeirensis vs & 1.1755 & 0.123 & -1.049 & 0.859 \\
\hline \multicolumn{5}{|l|}{ E. b. sinuensis } \\
\hline E. b. peruana vs & 0.8436 & 0.189 & 0.2023 & 0.345 \\
\hline \multicolumn{5}{|l|}{ E. b. poliocephala } \\
\hline E. $b$. peruana vs $E . b$. senex & 0.3441 & 0.31 & 1.7713 & 0.061 \\
\hline E. $b$. peruana vs E. $b$. sinuensis & -0.659 & 0.688 & -0.68 & 0.696 \\
\hline E. $b$. poliocephala vs $E$. $b$. senex & -0.024 & 0.507 & 0.6419 & 0.229 \\
\hline E. b. poliocephala vs & -0.204 & 0.593 & -0.093 & 0.47 \\
\hline \multicolumn{5}{|l|}{ E. b. sinuensis } \\
\hline E. b. senex vs E. b. sinuensis & -0.525 & 0.623 & 1.6284 & 0.076 \\
\hline
\end{tabular}

geographic areas, be diagnosably different morphologically and genetically, and have interfertile individuals (Haig et al. 2006; Patten 2010). Of the 16 subspecies of E. barbara, 15 had been named prior to 1920 based mainly on the taxonomic characters current at the time: body size and pelage coloration and pattern. Geography was not considered at that time, nor was having diagnosably different populations or that all individuals must be interfertile. It, therefore, is not surprising that many subspecies of $E$. barbara would not hold up to scrutiny under current subspecies concepts. Nonetheless, the objective of taxonomic studies is not simply to reject taxa but to reanalyze them to assess their validity and the consequences of using trinomials (Patten and Unitt 2002).

The current distribution of Eira barbara has been related to warm and humid forests of Central and South America (Schiaffini et al. 2017). Within the current Size and Pelage scheme and mtDNA scheme, not all subspecies are allopatric but they do share particular ecoregions (sensu Dinerstein et al. 2017): Central American dry forests are shared by E. b. senex and E. b. inserta; Guianan forests are shared by $E$. b. poliocephala and $E$. b. sinuensis; the Iquitos varzea forests are shared by $E$. b. madeirensis and $E$. $b$. peruana; the Magdalena moist forest by E. b. barbara and E. b. sinuensis. If biomes are the unit of analysis, rather than ecoregions, Tropical and Subtropical Moist (and Dry) Broadleaf Forests are inhabited by all subspecies. The Amazon basin (sensu lato), identified in a previous work as one of the most suitable areas for the presence of the species (Schiaffini et al. 2017), will include E. b. peruana, E. b. madeirensis, E. b. sinuensis, and $E$. b. poliocephala. Thus, recognized subspecies of $E$. barbara do not occupy distinct breeding ranges and as such, do not fulfill one of the three criteria for designating subspecies.

\section{Are any of the proposed schemes more reliable?}

Mean measures of skull morphology differ among subspecies using the Size and Pelage scheme but differences could not be observed in PCA plots, and Procrustes variances did not differ among subspecies. Thus, none of the subspecies currently can be diagnosed, violating the second criterion for designating subspecies. No individuals from a given subspecies can be identified as belonging to that subspecies rather than to another subspecies. Predictability (Patten and Unitt 2002) cannot be achieved.

Pelage coloration or pattern and body size have been the main traits used to define subspecies of E. barbara, as well as many other mammal species during 19th and early 20th centuries. Pelage coloration and pattern has not been evaluated as a useful taxonomic trait for E. barbara, but rather simply accepted and used (Cabrera 1958; Hall 1981; Presley 2000). Pelage coloration and patterns of E. barbara are particularly variable and throat patch variation even can be used to identify individuals within a population (Villafañe-Trujillo et al. 2018). The presence or absence of throat patches does not follow a geographic pattern (Villafañe-Trujillo et al. 2018). Presley (2000) stated that E. b. barbara has a "gray to brown head," E. b. madeirensis "may or may not have" a throat patch, and E. b. poliocephala is "similar to E. b. barbara but with a darker yellow throat patch and yellow shoulder patches, which 'sometimes' join forming a complete yellow collar" (bold added). The diagnostic traits of E. b. poliocephala, according to Traill (1821), are “...black body, head and neck dark grey; the throat marked with a yellowish angular spot, edged with black," which easily can be confused with traits in other putative subspecies as E. b. senex (M. Schiaffini, pers. obs., see pictures in Supplementary Data SD1). A possible shortcoming of the present study that must be mentioned is that I did not quantify specifically the changes in color of the skins (i.e., using a spectrophotometer). However, many skins stored in Mammals Collections date from beginning and middle of the 20th century and have been treated with various chemical substances as pesticides (Hawks and Williams 1986) that potentially could change the color and color patterns present in live individuals (Marte et al. 2006).

Putative mtDNA subspecies did not differ in mean measures of skull morphology. Procrustes variance suggested difference between E. b. barbara and E. b. peruana, but these differences were not supported by PCA analyses. Thus the third criterion for designating subspecies, that groups of populations are interfertile, means that two populations need not be reciprocally monophyletic because gene flow still exists (Patten 2010; Braby et al. 2012). Subspecies might be viewed within the unified species concept (de Queiroz 2007) as “...evolving populations that represent partially isolated lineages of a species that are allopatric, phenotypically distinct, have at least 

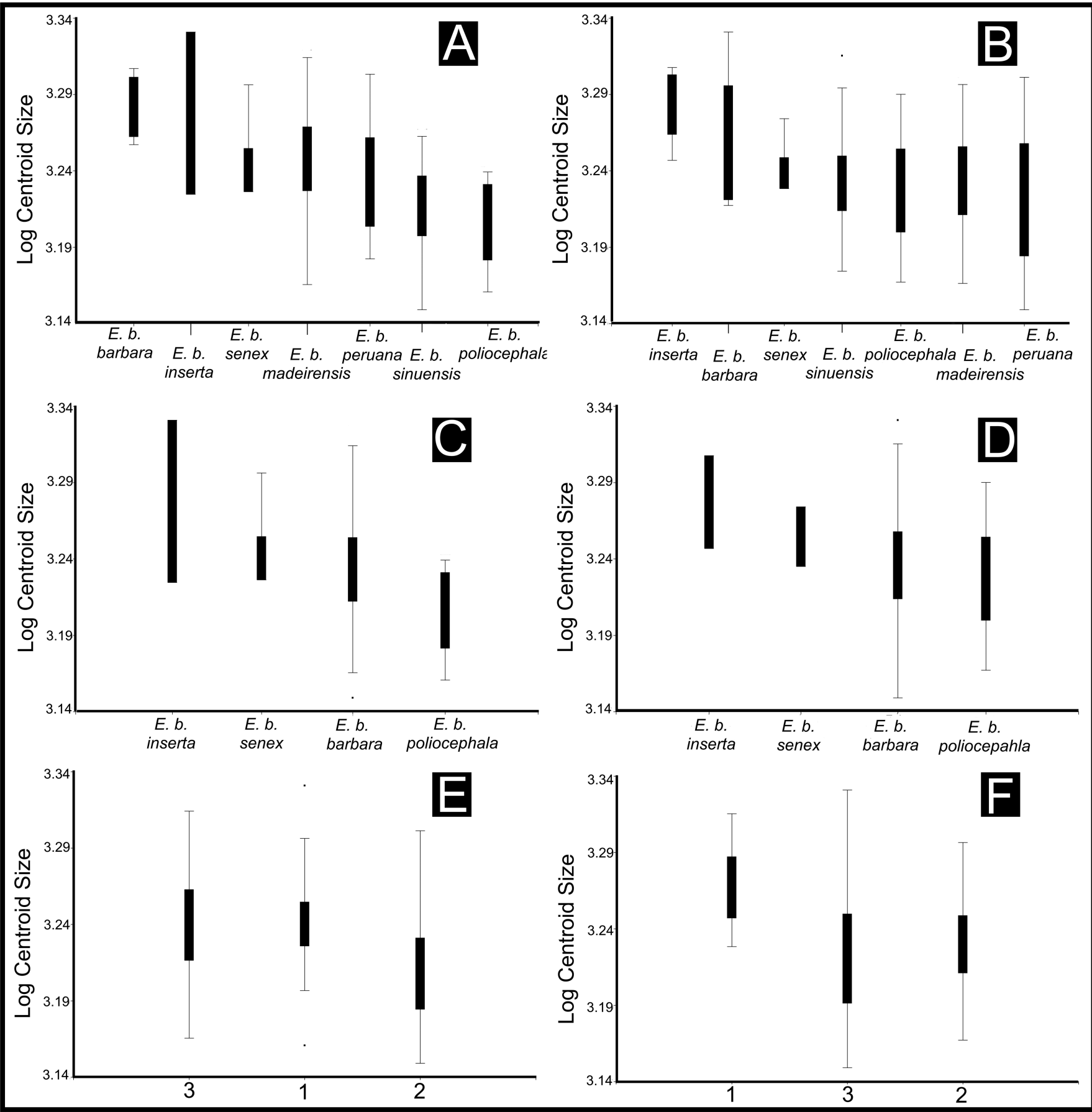

Fig. 3. - Boxplot of size differences (log-Centroid size) for skull in ventral view sensu Size and Pelage coloration scheme for (A) females, (B) males; sensu mitochondrial DNA scheme for (C) females, (D) males; and sensu geographic provenance for (E) females and (F) males.

one fixed diagnosable character state," and for which "character differences are ... correlated with evolutionary independence according to population genetic structure" (Braby et al. 2012). Although having isolated, phenotypically distinct groups is similar to the criterion for subspecies designation, having genetic structure might not be necessary. Subspecies are not the same as Evolutionary Significant Units (ESUs). Moritz (1994) defined Evolutionary Significant Units as being reciprocally monophyletic for mtDNA alleles and showing significant divergence of allele frequencies at nuclear loci. Subspecies are not expected to be reciprocally monophyletic (Patten 2010; Braby et al. 2012) and, therefore, the conceptual difference between Evolutionary Significant Units and subspecies is clear. Subspecies can be named as trinomials according to the International Code of Zoological Nomenclature (ICZN 1999: article 5.2), but Evolutionary Significant Units are not recognized in the ICZN and cannot be named as trinomials, although some ESUs may be synonymous with some subspecies, and vice versa.

Accepting mitochondrial DNA differences as the only evidence of taxonomic separation lacks the morphological 
Table 2.-Cross-validation scores using centroid size as variable and putative subspecies sensu Size and Pelage scheme, of females and males.

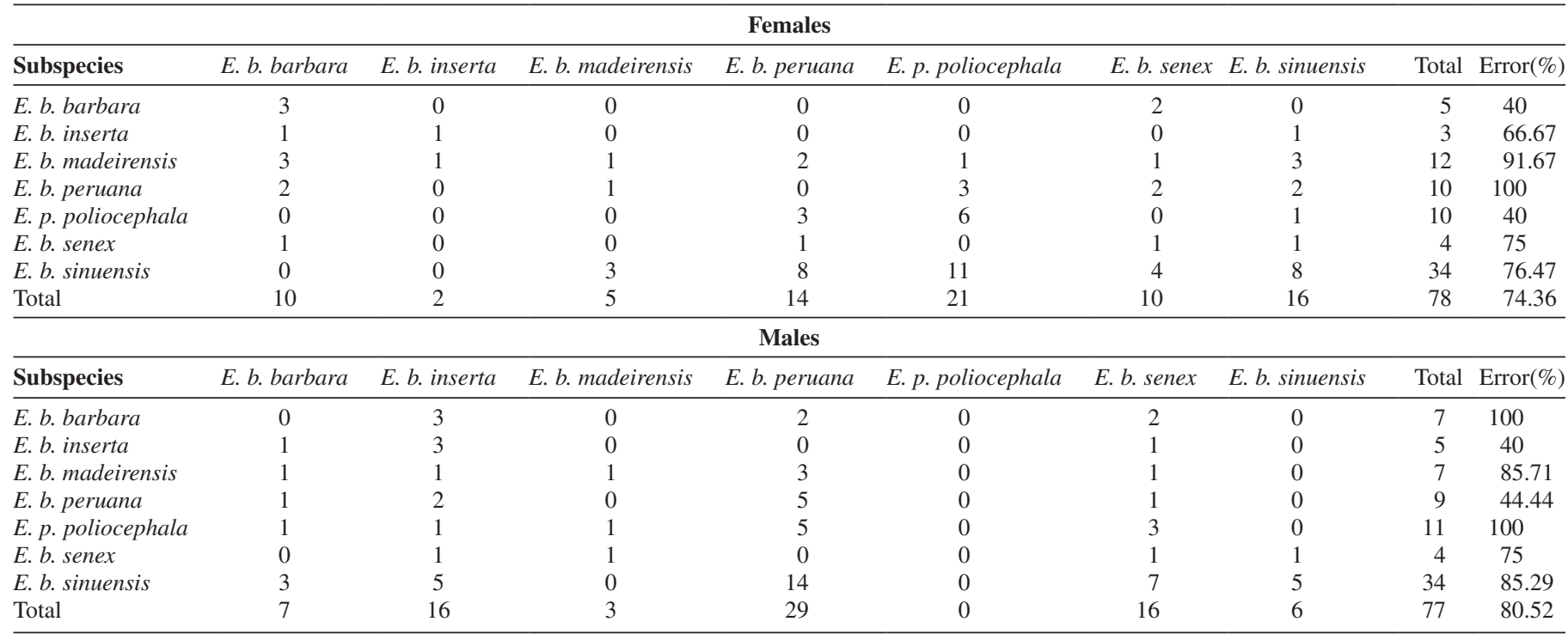

Table 3.-Pairwise ANOVA using 1,000 iterations using mean shape and Procrustes variance of skull shape (Procrustes coordinates) and putative subspecies sensu Mitochondrial DNA. In bold, significant values at $P<0.05$.

\begin{tabular}{|c|c|c|c|c|}
\hline \multirow[b]{2}{*}{ Subspecies pairs } & \multicolumn{2}{|c|}{ Mean } & \multicolumn{2}{|c|}{$\begin{array}{c}\text { Procrustes } \\
\text { Variance }\end{array}$} \\
\hline & $Z$ & $P$-value & $Z$ & $P$-value \\
\hline E. b. barbara vs E. $b$. inserta & -1.2503 & 0.903 & 0.9873 & 0.12 \\
\hline E. $b$. barbara vs E. $b$. poliocephala & -0.4893 & 0.686 & 0.7761 & 0.199 \\
\hline E. $b$. barbara vs $E . b$. senex & -0.1795 & 0.596 & 2.6339 & $\mathbf{0 . 0 3}$ \\
\hline E. $b$. inserta vs $E$. $b$. poliocephala & -0.8580 & 0.794 & 0.1723 & 0.343 \\
\hline E. $b$. inserta vs $E . b$. senex & 0.4281 & 0.333 & 0.1570 & 0.34 \\
\hline E. b. poliocephala vs E. b. senex & -0.0381 & 0.528 & 1.7377 & 0.06 \\
\hline
\end{tabular}

diagnosability dimension of the subspecies concept. Molecular analysis (and particularly single-gene molecular analysis) should be integrated with morphology (Moritz and Cicero 2004). Only using mtDNA to analyze taxa boundaries has known limitations, due to introgression, retention of ancestral polymorphisms, and male-biased dispersal (Moritz and Cicero 2004). If E. barbara has the expected pattern of philopatric females and dispersing males, then higher genetic differentiation among populations is expected from analyzing only maternal markers compared with whole genome markers (Prugnolle and de Meeus 2002). This situation might explain the differences between results using morphometric analysis and those using maternal markers for E. barbara (Ruiz-García et al. 2013; Mejía-Young 2018). Unfortunately, mating and dispersal systems for wild E. barbara are unknown. A few published comments imply that females are philopatric while males are the primary dispersers and do not help raise young (Gaumer 1917; Kaufmann and Kaufmann 1967; Presley 2000). PoglayenNeuwall $(1975,1978)$ described reproductive behavior in captivity.
The three groups that were recognized by the geographical provenance scheme are consistent with the limited fossil record, which suggests that E. barbara initially differentiated as a species in Central American (Schiaffini et al. 2017) and subsequently colonized northwestern Colombia, where the species range split into two branches, one extending east to occupy forested areas of Venezuela and Guyana (group 2), the other south as far as northern Argentina (group 3). The three geographical groups exhibit no differentiation of mean skull shape or of Procrustes variance and show no segregation in PCA plots.

Cross-validation scores for all three subspecies schemes for E. barbara had high error rates. Useful traits for describing subspecies must be geographically variable (Mayr 1982; Mayr and Ashlock 1991; Patten 2010). Different subspecies schemes yielded different results for analyses of skull size, illustrating the risk of considering arbitrary groupings of a variable and seeking differences among them (Patten and Unitt 2002).

\section{Geographic variation and environmental conditions}

For E. barbara, environmental variables correlated with small but significant percentages of the variation of skull size: temperature and seasonality of precipitation correlated inversely with skull size, while net primary productivity correlated positively. Bergmann's rule (Bergmann 1847) does not apply to E. barbara. McNab's (2010) Resources Rule did explain the small amount of the variation of skull size. Thus environmental variables explained much less size variation than did other analyses using similar methodologies (see Schiaffini 2016; Schiaffini et al. 2019). Those analyses were however, of carnivorans inhabiting temperate environments, suggesting the hypothesis that taxa from tropical environments might be less prone to vary with climatic conditions than are those from higher latitudes. Temperate regions of South America 
Table 4.-Cross-validation scores using centroid size as variable and putative subspecies sensu mitochondrial DNA scheme, of females and males.

\begin{tabular}{|c|c|c|c|c|c|c|}
\hline \multicolumn{7}{|c|}{ Females } \\
\hline Subspecies & E. b. barbara & E. b. inserta & E. p. poliocephala & E. b. senex & Total & Error $(\%)$ \\
\hline E. b. barbara & 19 & 9 & 20 & 13 & 61 & 68.85 \\
\hline E. $b$. inserta & 1 & 2 & 0 & 0 & 3 & 33.33 \\
\hline E. p. poliocephala & 3 & 0 & 7 & 0 & 10 & 30 \\
\hline E. b. senex & 2 & 1 & 0 & 1 & 4 & 75 \\
\hline Total & 25 & 12 & 27 & 14 & 78 & 62.82 \\
\hline \multicolumn{7}{|c|}{ Males } \\
\hline Subspecies & E. b. barbara & E. b. inserta & E.p.poliocephala & E. b. senex & Total & Error $(\%)$ \\
\hline E. b. barbara & 10 & 12 & 26 & 12 & 60 & 83.33 \\
\hline E. $b$. inserta & 0 & 2 & 0 & 1 & 3 & 33.33 \\
\hline E. p. poliocephala & 0 & 1 & 6 & 4 & 11 & 45.45 \\
\hline E. b. senex & 1 & 1 & 0 & 1 & 3 & 66.67 \\
\hline Total & 11 & 16 & 32 & 18 & 77 & 75.32 \\
\hline
\end{tabular}

Table 5.-Pairwise ANOVA using 1,000 iterations using mean shape and Procrustes variance of skull shape (Procrustes coordinates) and putative subspecies sensu geographical provenance.

\begin{tabular}{lrrrrr}
\hline & \multicolumn{2}{c}{ Mean } & & \multicolumn{2}{c}{ Procrustes variance } \\
\cline { 2 - 3 } \cline { 6 - 7 } Geographic groups & $Z$ & & $P$-value & & \multicolumn{1}{c}{$Z$-value } \\
\hline 1 versus 2 & -1.1278 & 0.886 & & -0.1513 & 0.494 \\
1 versus 3 & 1.5570 & 0.055 & & 0.3414 & 0.314 \\
2 versus 3 & -0.2440 & 0.579 & & -0.7908 & 0.735 \\
\hline
\end{tabular}

Table 6.-Cross-validation scores using centroid size as variable and putative subspecies following geographic provenance, of females and males.

\begin{tabular}{lrrrll}
\hline \multicolumn{5}{c}{ Females } \\
\hline Group & 1 & 2 & 3 & Total & Error $(\%)$ \\
\hline 1 & 4 & 6 & 8 & 18 & 77.78 \\
2 & 5 & 21 & 3 & 29 & 27.59 \\
3 & 5 & 10 & 16 & 31 & 48.39 \\
Total & 14 & 37 & 27 & 78 & 47.44 \\
\hline \multicolumn{7}{c}{ Males } \\
\hline Group & 1 & 2 & 3 & Total & Error (\%) \\
\hline 1 & 12 & 6 & 1 & 19 & 36.84 \\
2 & 8 & 8 & 16 & 32 & 75 \\
3 & 7 & 6 & 13 & 26 & 50 \\
Total & 27 & 20 & 30 & 77 & 57.14 \\
\hline
\end{tabular}

host many dry habitats with extreme minimum temperatures, low precipitation, and high seasonality (Abraham et al. 2009; Garreaud et al. 2009). Eira barbara is limited to forested environments in tropical and subtropical Americas where environmental conditions are less variable than conditions in temperate regions (Hijmans et al. 2005). This seems to be in agreement with the notion that higher-latitude environments display higher seasonality (Boyce 1979). Not much information is available as to geographic variation in South American mustelids. However, Ralls and Harvey (1985) did find that the size of $M$. frenata does not vary with latitude in North America, and affects size of other sympatrically distributed
Mustela species. For Galictis cuja (Molina 1782), around $10 \%$ of size variation has been related to precipitation and altitude (Schiaffini 2014); the same work also found that smaller specimens of Lyncodon patagonicus (de Blainville 1842) came from dry environments. The importance of geographic and environmental variation to understand the limits of intraspecific variation and the proper use of infraspecific taxonomy deserves more attention.

Size in E. barbara varied somewhat with climate but varied most between sexes, showing marked sexual size dimorphism (SSD). Many studies have addressed this subject and need not be discussed here (e.g., Moors 1980; Dayan et al. 1990; Dayan and Simberloff 2005; Meiri et al. 2005). The SSD expressed in E. barbara might respond to two widely accepted theories: as a mechanism to avoid intraspecific competition, but also because in polygynous species males, are larger due to sexual selection, and females are smaller to invest more energy in the rearing of the litters (Moors 1980).

The 16 subspecies of E. barbara were originally described on the basis of characters that are highly variable within populations (e.g., pelage coloration and pattern), between sexes, and across environments (e.g., body size). None of the three schemes for subspecies that I analyzed is reliable for subspecies designations. Subspecies based on body size and pelage and based on mtDNA lack geographic isolation and analyses of $E$. barbara specimens across three distinct geographical regions within the (presumed) continuous distribution of the species lacked diagnosable characters for body size and pelage coloration, for mitochondrial DNA, or for morphology of skulls, that could be assigned to aggregations of populations within the species. Thus, none of the presently accepted subspecies of $E$. barbara can be recognized as valid taxa, and trinomials should not be applied.

Eira barbara is not unique among polytypic South American mammal species in containing subspecies that have been described without a proper conceptual framework, a phenomenon that regrettably also applied to species themselves. Applying trinomials to populations that are not geographically isolated nor phenotypically identifiable leads to criticism of the concept. 
Table 7.- Results from OLS between centroid size and environmental variables. The third Spatial Filter was used as covariable in male dataset, and the first Spatial Filter in female dataset. In bold, significant values at $P<0.05$.

\begin{tabular}{|c|c|c|c|c|c|c|}
\hline \multirow[b]{2}{*}{ Independent variable } & \multicolumn{3}{|c|}{ Males } & \multicolumn{3}{|c|}{ Females } \\
\hline & $R 2$ adj ind. variable & $P$-value ind. variable & Slope & $R 2$ adj ind. variable & $P$-value ind. variable & Slope \\
\hline Annual mean temperature & 0.02 & 0.17 & -0.141 & 0.028 & 0.128 & -0.056 \\
\hline Mean diurnal range & $<0.001$ & 0.969 & 0.003 & 0.007 & 0.438 & 0.053 \\
\hline Isothermality & 0.013 & 0.261 & -0.119 & 0.065 & 0.018 & -0.205 \\
\hline Annual precipitation & $<0.001$ & 0.987 & 0.001 & 0.002 & 0.656 & 0.01 \\
\hline Precipitation Seasonality & 0.044 & 0.038 & -0.047 & 0.001 & 0.507 & 0.014 \\
\hline Net primary productivity & 0.025 & 0.121 & 0.059 & 0.04 & 0.066 & 0.061 \\
\hline Potential Evapotranspiration & 0.002 & 0.673 & -0.018 & 0.047 & 0.046 & -0.073 \\
\hline Enhanced vegetation index & 0.002 & 0.703 & 0.013 & $<0.001$ & 0.825 & -0.05 \\
\hline
\end{tabular}

Table 8.- - Results from model averaging of six models with $\triangle \mathrm{AIC}$ $<2$ of male dataset.

\begin{tabular}{lccc}
\hline Parameter & Estimate & $\begin{array}{c}\text { Relative } \\
\text { Importance }\end{array}$ & $\begin{array}{c}\text { Standard } \\
\text { Error }\end{array}$ \\
\hline (Intercept) & 3.5522 & - & 0.1631 \\
Spatial Filter & 0.1882 & 1 & 0.0403 \\
Precipitation seasonality & -0.0468 & 0.89 & 0.0237 \\
Net primary productivity & 0.0417 & 0.22 & 0.0412 \\
Isothermality & -0.1186 & 0.19 & 0.1024 \\
Annual mean temperature & -0.1036 & 0.16 & 0.1017 \\
Annual precipitation & -0.0207 & 0.14 & 0.0246 \\
\hline
\end{tabular}

Table 9.- Results from model averaging of nine models with $\triangle \mathrm{AIC}$ $<2$ of female dataset.

\begin{tabular}{lrcc}
\hline Parameter & Estimate & $\begin{array}{c}\text { Relative } \\
\text { Importance }\end{array}$ & $\begin{array}{c}\text { Standard } \\
\text { Error }\end{array}$ \\
\hline (Intercept) & 3.6802 & & 0.38 \\
Spatial Filter & -0.0888 & 1 & 0.04 \\
Isothermality & -0.1851 & 1 & 0.09 \\
Net primary productivity & 0.0697 & 0.75 & 0.04 \\
Potential Evapotranspiration & -0.0483 & 0.36 & 0.04 \\
Mean diurnal range & 0.1095 & 0.36 & 0.08 \\
Annual mean temperature & -0.0438 & 0.22 & 0.04 \\
Annual precipitation & 0.0278 & 0.07 & 0.02 \\
\hline
\end{tabular}

The vigorous debate stimulated by Wilson and Brown (1953) continues.

\section{ADDENDUM}

The correct publication date of the genus Lyncodon, usually is regarded as Gervais 1845, actually is 1844 (Palmer 1904; Simpson 1945). Accordingly, the correct name should be Lyncodon Gervais 1844.

\section{ACKNOWLeDgMents}

I thank people in charge of the collections for allowing access to specimens under their care: Nancy Simmons and Eileen Westwig (AMNH), Bruce Patterson (FMNH), Pablo Teta and Sergio Lucero (MACN), Don Wilson and Darrin Lunde (USNM). The FMNH and USNM collections were visited thanks to Grants from Field Museum of Natural History and
Smithsonian Institution, sponsored by Bruce Patterson and Don Wilson, respectively. To both of them, my deepest gratitude. Dr. Alvaro Mones helped me with the correct year of publication of the genus Lyncodon. Thanks to Pancho Prevosti for their comments and discussion. Michael Patten provided very valuable comments that help to improve the manuscript. I thank Roger Powell for the time and effort invested in the reading and editing of the manuscript. Finally, the manuscript was greatly improved by the comments of Editors and two anonymous reviewers. I also thank Agencia Nacional de Promoción Científica y Tecnológica (PICT 2016-0238) for partial financial support.

\section{SUPPLEMENTARY DATA}

Supplementary data are available at Journal of Mammalogy online.

Supplementary Data SD1. Pictures of skins of E. b. poliocephala (A) and E. b. senex (B) from USNM showing similar coat pattern.

Supplementary Data SD2. Description of landmarks used in geometric morphometric analysis.

\section{Literature Cited}

Abraham, E., ET AL. 2009. Overview of the geography of the Monte Desert biome (Argentina). Journal of Arid Environments 73:144-153.

Adams, D., M. Collyer, And A. Kaliontzopoulou. 2019. Geomorph: software for geometric morphometric analyses. R package version 3.1.0. https://cran.rproject.org/package=geomorph. Accessed on 17 May 2019.

AKaike, H. 1973. Information theory as an extension of the maximum likelihood principle, Pp. 267-281 in Second International Symposium on Information Theory (B. N. Petrov and F. Csaki, eds.). Akademiai Kiado. Budapest, Hungary.

Allen, J. A. 1904. Mammals from southern Mexico and Central and South America. Bulletin of the American Museum of Natural History 20:29-80.

Allen, J. A. 1908. Mammals from Nicaragua. Bulletin of the American Museum of Natural History 24:647-670.

Allen, J. A. 1913. New mammals from Colombia and Ecuador. Bulletin of the American Museum of Natural History 31:469-484.

Allen, J. A. 1916. Mammals collected on the Roosevelt Brazilian expedition, with field notes by Leo E. Miller. Bulletin of the American Museum of Natural History 35:559-610. 
Amadon, D. 1949. The seventy-five percent rule for subspecies. The Condor 51:250-258.

BARTón, K. 2019. MuMIn: multi-model inference. R package, version 1.43.6. http://r-forge.r-project.org/projects/mumin. Accessed on 21 May 2019.

Baryshnikov, G. F., AND A. V. Abramov. 1997. Structure of baculum (os penis) in Mustelidae (Mammalia, Carnivora), Communication 1. Zoologichesky Zhurnal 76:1399-1410.

Bell, T. 1826. Zoological Club, 10 January 1826. The Zoological Journal 2:548-554.

Bergmann, C. 1847. Ueber die Verhältnisse der Wärmeökonomie der Thiere zu ihrerGrösse. Gottinger Studien 3:595-708.

Bonaparte, C. L. 1838. Synopsis vertebratorum systematis. Nuovi Annali delle Scienze Naturali 1:105-133.

Boyce, M. S. 1979. Seasonality and patterns of natural selection for life histories. The American Naturalist 114:569-583.

Braby, M. F., R. Eastwood, and N. Murray. 2012. The subspecies concept in butterflies: has its application in taxonomy and conservation biology outlived its usefulness? Biological Journal of the Linnean Society 106:699-716.

Burbrink, F. T., R. Lawson, and J. B. Slowinski. 2000. Mitochondrial DNA phylogeography of the polytypic North American rat snake (Elaphe obsoleta): a critique of the subspecies concept. Evolution 54:2107-2118.

Cabrera, A. L. 1958. Catálogo de los Mamíferos de América del Sur, Metatheria-Unguiculata-Carnivora. Revista del Museo Argentino de Ciencias Naturales "Bernardino Rivadavia" 4:i-iv + 1-308.

ChatterJee, S., ANd A. S. Hadi. 2006. Regression analysis by example. 4th ed. John Wiley \& Sons. Hoboken, New Jersey.

Collyer, M. L., AND D. C. Adams. 2018. RRPP: an r package for fitting linear models to high-dimensional data using residual randomization. Methods in Ecology and Evolution 9:1772-1779.

Collyer, M. L., And D. C. Adams. 2019. RRPP: Linear model evaluation with randomized residuals in a permutation procedure. https://CRAN.R-project.org/package=RRPP. Accessed on 17 May 2019.

Collyer, M. L., D. J. Sekora, And D. C. Adams. 2015. A method for analysis of phenotypic change for phenotypes described by high-dimensional data. Heredity 115:357-365.

Dayan, T., And D. Simberloff. 1994. Character displacement, sexual dimorphism, and morphological variation among British and Irish mustelids. Ecology 75:1063-1073.

Dayan, T., ANd D. Simberloff. 2005. Ecological and communitywide character displacement: the next generation. Ecology Letters 8:875-894.

Dayan, T., D. Simberloff, E. Tchernov, and Y. Yom-Tov. 1990. Feline canines: community-wide character displacement among the small cats of Israel. The American Naturalist 136:39-60.

DE Blainville, H. M. D. 1842. Ostéographie ou description iconographique comparée du squelette et du systéme dentaire des mammifères récents et fossiles des cinq classes d'animaux vertébrés récents et fossiles our sevir de base à la zoologie et à la géologie. A. Bertrand. Paris, France.

De Queiroz, K. 2007. Species concepts and species delimitation. Systematic Biology 56:879-886.

Dinerstein, E., ET AL. 2017. An ecoregion-based approach to protecting half the terrestrial realm. Bioscience 67:534-545.

Diniz-Filho, J. A. F., AND L. M. Bini. 2005. Modelling geographic patterns in species richness using eigenvector-based spatial filters. Global Ecology and Biogeography 14:177-185.
Diniz-Filho, J. A. F., T. F. L. V. B. Rangel, And L. M. Bini. 2008 Model selection and information theory in geographical ecology. Global Ecology and Biogeography 17:479-488.

Dormann, C. F., ET AL. 2013. Collinearity: a review of methods to deal with it and a simulation study evaluating their performance. Ecography 36:027-046.

Emmons, L. H., AND F. Freer. 1990. Neotropical rainforest mammals: a field guide. University of Chicago Press, Chicago, Illinois.

Ercoli, M. D., and D. Youlatos. 2016. Integrating locomotion, postures and morphology: the case of the tayra, Eira barbara (Carnivora, Mustelidae). Mammalian Biology 81:464-476.

Fischer von Waldheim, G. 1817. Adversaria Zoologica. Mémoire de la Société Impériale des Naturalistes de Moscou 5:357-471.

Foley, J. A., ET AL. 1996. An integrated biosphere model of land surface processes, terrestrial carbon balance, and vegetation dynamics. Global Biogeochemichal Cycles 10:603-628.

Fox, J., AND S. Weisberg. 2011. An \{R\} companion to applied regression. 2nd ed. Sage Publications. Thousand Oaks, California.

Garreaud, R. D., M. Vuille, R. Compagnucci, and J. Marengo. 2009. Present-day South American climate. Palaeogeography, Palaeoclimatology, Palaeoecology 281:180-195.

Gaumer, G. F. 1917. Mamíferos de Yucatán. Dept. Talleres Gráficos, Secretaría de Fomento. Mexico City, Mexico.

Gervais, P. 1844. DENTS. Zool. Pp. 676-694 in Dictionnaire universel d'histoire naturelle (C. d'Orbigny, ed.). Bureau Principal des Éditeurs. Paris, France.

Gilham, N. W. 1956. Geographic variation and the subspecies concept in butterflies. Systematic Zoology 5:110-120.

GipPoliti, S., AND G. Amori. 2007. The problem of subspecies and biased taxonomy in conservation lists: the case of mammals. Folia Zoologica 56:113-117.

Goodall, C. 1991. Procrustes methods in the statistical analysis of shape. Journal of the Royal Statistical Society 52:285-339.

Gosline, W. A. 1954. Further thoughts on subspecies and trinomials. Systematic Zoology 3:92-94.

Gray, J. E. 1825. An outline of an attempt at the disposition of Mammalia into tribes and families, with a list of the genera apparently appertaining to each tribe. Annals of Philosophy 10:337-344.

Gray, J. E. 1837. Description of some new or little known Mammalia, principally in the British Museum collection. Magazine of Natural History 1:577-587.

Gray, J. E. 1843. Descriptions of some new genera and species of Mammalia in the British Museum collection. Annals and Magazine of Natural History 11:117-119.

Griffith, E. 1827. The third order of the Mammalia. The Carnassiers. Pp. 1-516 in The Animal Kingdom arranged in conformity with its organization by the Baron Cuvier. Volume The Second. The Class Mammalia; Arranged by the Baron Cuvier. Printed by William Clowes for George B. Whittaker. London, United Kingdom.

Groves, C. 2012. Species concept in Primates. American Journal of Primatology 00:1-5.

Grueber, C. E., S. Nakagawa, R. J. Laws, and I. G. Jamieson. 2011. Multimodel inference in ecology and evolution: challenges and solutions. Journal of Evolutionary Biology 24:699-711.

HaIG, S. M., ET AL. 2006. Taxonomic considerations in listing subspecies under the U.S. Endangered Species Act. Conservation Biology: The Journal of the Society for Conservation Biology 20:1584-1594.

Hall, E. R. 1981. The mammals of North America. 2nd ed. John Wiley \& Sons. New York. 
Hawkins, B. A. 2008. Eight (and a half) deadly sins of spatial analysis. Journal of Biogeography 39:1-9.

Hawks, C. A., AND S. L. Williams. 1986. Arsenic in natural history collections. Leather Conservation News 2:1-4.

Hijmans, R. J., S. E. Cameron, J. L. Parra, P. G. Jones, and A. JARVIS. 2005. Very high resolution interpolated climate surfaces for global land areas. International Journal of Climatology 25:1965-1978

International Code of Zoological Nomenclature. 1999. 4th ed. International Trust for Zoological Nomenclature. London, United Kingdom.

Jolliffe, I. T. 2002. Principal Component Analysis. 2nd ed. SpringerVerlag, New York.

Kaufmann, J. H., and A. Kaufmann. 1967. Observations of the behavior of Tayras and Grisons. Zeitschrift für Säugertierkunde 30:146-155.

Kissling, W. D., And G. Carl. 2007. Spatial autocorrelation and the selection of simultaneous autoregressive models. Global Ecology and Biogeography 17:59-71.

Koepfli, K. P., ET AL. 2008. Multigene phylogeny of the Mustelidae: resolving relationships, tempo and biogeographic history of a mammalian adaptative radiation. BMC Biology 6:10.

Krumbiegel, V. I. 1942. Die säugetiere der Südamerika-expeditionen Prof. Dr. Kriegs. Zoologischer Anzeiger 139:81-96.

Kucharik, C. J., ET AL. 2000. Testing the performance of a Dynamic Global Ecosystem Model: water balance, carbon balance, and vegetation structure. Global Biogeochemichal Cycles 14:795-825.

Larivière, S., and A. P. Jennings. 2009. Familiy Mustelidae. Pp. 564-632 in Handbook of the mammals of the world (D. E. Wilson, and R. A. Mittermeier, eds.). Lynx Editions. Barcelona, Spain.

Li, B., M. Wolsan, D. Wu, W. Zhang, Y. Xu, and Z. Zeng. 2014. Mitochondrial genomes reveal the pattern and timing of marten (Martes), wolverine (Gulo), and fisher (Pekania) diversification. Molecular Phylogenetics and Evolution 80:156-164.

Lichtenstein, H. 1831. Darstellung neuer oder wenig bekannter Säugethiere in Abbildungen und Beschreibungen von Fünf und Sechzig Arten auf Funfzig Colorirten Steindrucktafeln nach den Originalen des Zoologischen Museums der Universität zu Berlin. C. G. Luderitz. Berlin, Germany.

Linnaeus, C. 1758. Sistema naturæ per regna tria naturæ, secundum classes, ordines, genera, species, cum characteribus, differentiis, synonymis, locis; Editio decima, reformata, v. 1: Regnum animale. Laurentii Salvii. Stockholm, Sweden.

LÖNNBERG, E. 1913. Mammals from Ecuador and related forms. Arkiv för Zoologi 8:1-36.

Marantz, C. A., And M. A. Patten. 2010. Quantifying subspecies analysis: a case study of morphometric variation and subspecies in the woodcreeper genus Dendrocolaptes. Ornithological Monographs 67:123-140.

Marte, F., A. Péquignot, and D. W. Von Endt. 2006. Arsenic in taxidermy collections: history, detection and management. Collection Forum 21:143-150.

Martínez, F. 1873. Notas sobre mamíferos Americanos. Anales de la Sociedad Española de Historia Natural 2:239-247.

MAYr, E. 1942. Systematics and the origin of species. Columbia University Press. New York.

MAYR, E. 1954. Notes on nomenclature and classification. Systematic Zoology 3:86-89.

MAYr, E. 1982. Of what use are subspecies? The Auk 99:593-595.

Mayr, E., AND P. D. Ashlock. 1991. Principles of Systematic Zoology. 2nd ed. MacGraw Hill. New York.
Mayr, E., G. Linsley, And R. L. Usinger. 1953. Methods and Principles of Systematic Zoology. MacGraw Hill. New York.

McNAB, B. K. 2010. Geographic and temporal correlations of mammalian size reconsidered: a resource rule. Oecologia 164:13-23.

Meiri, S., T. Dayan, and D. Simberloff. 2005. Variability and sexual size dimorphism in carnivores: testing the niche variation hypothesis. Ecology 86:1432-1440.

Mejía Young, Y. 2018. Filogeografía de la taira Eira barbara (Carnivora: Mustelidae) a través de su rango de distribución, mediante marcadores moleculares. M.S. thesis. Pontificia Universidad Javeriana. Bogotá, Colombia.

Molina, G. I. 1782. Saggio sulla storia naturale del Chili. Stamperia di Sto. Tommaso d'Aquino. Bologna, Italy.

Moors, P. J. 1980. Sexual dimorphism in the body size of mustelids (Carnivora). The role of food habits and breeding systems. Oikos 34:147-158.

Moritz, C. 1994. Defining "Evolutionarily Significant Units" for conservation. Trends in Ecology and Evolution 9:373-375.

MoritZ, C., AND C. Cicero. 2004. DNA barcoding: promise and pitfalls. PLoS Biology 2:1529-1531.

Morrone, J. J., AND J. V. Crisci. 1995. Historical biogeography: introduction to methods. Annual Review of Ecology and Systematics 26:373-401.

Nehring, A. 1886. Beiträge zur Kenntiss der Galictis-Arten. Zoologische Jahrbucher, Zeitschrift für Systematik, Geographie und Biologie der Thiere 1:177-212.

O'BRIEN, S. J., AND E. MAYR. 1991. Bureaucratic mischief: recognizing endangered species and subspecies. Science (New York, N.Y.) 251:1187-1188.

PALmer, T. S. 1904. Index generum mammalium: a list of the genera and families of mammals. North American Fauna no. 23. U.S Department of Agriculture. Division of Biological Survey, Washington, D.C.

Patten, M. A. 2010. Null expectations in subspecies diagnosis. Ornithological Monographs 67:35-41.

Patten, M. A. 2015. Subspecies and the philosophy of science. The Auk 132:481-485.

Patten, M. A., And P. Unitt. 2002. Diagnosability versus mean differences of Sage Sparrow subspecies. The Auk 119:26-35.

Patton, J. L., and C. J. Conroy. 2017. The conundrum of subspecies: morphological diversity among desert populations of the California vole (Microtus californicus, Cricetidae). Journal of Mammalogy 98: 1010-1026.

Pocock, R. I. 1922. On the external characters and classification of the Mustelidae. Proceedings of the Zoological Society of London 1921:803-837.

Poglayen-Neuwall, I. 1975. Copulatory behavior, gestation and parturition of the tayra (Eira barbara L., 1758). Zeitschrift für Säugertierkunde 40:176-189.

Poglayen-Neuwall, I. 1978. Breeding, rearing and notes on the behavior of tayras Eira barbara in captivity. International Zoo Yearbook 18:134-140.

Presley, S. J. 2000. Eira barbara. Mammalian Species 636:1-6.

Prugnolle, F., AND T. DE Meeus. 2002. Inferring sex-biased dispersal from population genetic tools: a review. Heredity 88:161-165.

R Development Core Team. 2018. R: a language and environment for statistical computing. R Foundation for Statistical Computing. Vienna, Austria.

Ralls, K., AND P. H. Harvey. 1985. Geographic variation in size and sexual dimorphism of North American weasels. Biological Journal of the Linnean Society 25:119-167. 
Rangel, T. F., J. A. F. Diniz-Filho, and L. M. Bini. 2010. SAM: a comprehensive application for spatial analysis in macroecology. Ecography 33:1-5.

Remsen, J. V., JR. 2010. Subspecies as a meaningful taxonomic rank in avian classification. Ornithological Monographs 67:6-78.

RoHLF, J. F. 1999. Shape statistics: procrustes superimpositions and tangent spaces. Journal of Classification 16:197-223

RohlF, J. F. 2017. TPS Util Ecology and Evolution, SUNY at Stony Brook. https://life.bio.sunysb.edu/morph/soft-dataacq.html. Accessed on 1 October 2018.

Ruiz-García, M., N. Lichilín-Ortiz, and M. F. JaRAmillo. 2013. Molecular phylogenetics of two neotropical carnivores, Potos flavus (Procyonidae) and Eira barbara (Mustelidae): no clear existence of putative morphological subspecies. Pp. 37-84 in Molecular population genetics, evolutionary biology and biological conservation of netropical carnivores (M. Ruiz-García and J. M. Shostell, eds.). Nova publishers. New York.

SATO, J. J., ET AL. 2012. Evolutionary and biogeographic history of weasel-like carnivorans (Musteloidea). Molecular Phylogenetics and Evolution 63:745-757.

SchiafFini, M. I. 2014. Ensambles de pequeños carnívoros (Carnivora: Mustelidae y Mephitidae) en Patagonia: taxonomía, distribución y repartición trófica. Doctoral dissertation. Universidad Nacional de La Plata. La Plata, Argentina.

Schiaffini, M. I. 2016. A test of the Resource's and Bergmann's rules in a widely distributed small carnivore from southern South America, Conepatus chinga (Molina, 1782) (Carnivora: Mephitidae). Mammalian Biology 81:73-81.

Schiaffini, M. I., F. J. Prevosti, B. S. Ferrero, and J. I. Noriega. 2017. A Late Pleistocene Guloninae (Carnivora, Mustelidae) from South America (Argentina, Entre Ríos province), biogeographic implications. Journal of South American Earth Sciences 78:141-149.

Schiaffini, M. I., V. Segura, And F. J. Prevosti. 2019. Geographic variation in skull shape and size of the Pampas fox Lycalopex gymnocercus (Carnivora: Canidae) in Argentina. Mammalian Biology 97:50-58.

SheEts, H. D. 2002. IMP-integrated morphometrics package. Departments of Physics. Canisius College. Buffalo, NY.

Simpson, G. G. 1945. The principles of classification and the classification of mammals. Bulletin of the American Museum of Natural History, 85:i-xvi+1-350.

Smith, C. H. 1842. Introduction to Mammalia. Pp. 1-313 in The Naturalist's Library (W. Jardine, ed.). Printed by J. Ogden and Co. London, United Kingdom.

Stanford, C. B. 2001. The subspecies concept in primatology: the case of mountain gorillas. Primates 42:309-318.

Thomas, O. 1900. The geographical races of the tayra (Galictis barbara), with notes on abnormally coloured individuals. Annals and Magazine of Natural History 7:145-148.

Thomas, O. 1901. New Mammals from Peru and Bolivia, with a list of those recorded from the Inambari River, Upper Madre de Dios. The Annals and Magazine of Natural History, including Zoology, Botany and Geology 7:178-190.

Traill, S. 1821. Account of the Lutra vittata, and of the Viverra poliocephalus. Memoirs of the Wernerian Natural History Society 3:437-441.

VAN Gelder, R. G. 1968. The genus Conepatus (Mammalia, Mustelidae): variation within a population. American Museum Novitates 2322:1-37.

Villafañe-Trujillo, A. J., C. A. López-González, AND J. M. KolowsKI. 2018. Throat patch variation in the tayra (Eira barbara) and the potential for individual identification in the field. Diversity 10:7.

von Humboldt, A. DE F. H. A. 1812. Tableau synoptique des singes de l'Ameriqe. Pp. 343-363 in Voyage aux regions equinoxiales $\mathrm{du}$ nouveau continent fait en 1799-1804. Pt. II. Recueil d'observations de zoologie et d'anatomie comparée (A. Humboldt, and A. Bonpland, eds.). Chez F. Schoell, Libraire. Paris, France.

VoN Tschudi, J. J. 1844-1846. Untersuchungen über die Fauna Peruana. Druck und Verlag von Scheitlin und Zollikofer. St. Gallen, Switzerland.

Willmott, C. J., And K. MatsuUra. 2001. Terrestrial water budget data archive: monthly time series (1950-1999). Center for Climate Research, University of Delaware. Newark, Delaware. www.sage. wisc.edu/atlas/maps.php?catnum3\&typeEcosystems/.

Wilson, E. O., AND W. L. Brown, JR. 1953. The subspecies concept and its taxonomic application. Systematic Zoology 2:97-111.

Wolsan, M., And M. Sotnikova. 2013. Systematics, evolution, and biogeography of the Pliocene stem meline badger Ferinestrix (Carnivora: Mustelidae). Zoological Journal of the Linnean Society 167:208-226.

Wozencraft, W. C. 2005. Order Carnivora. Pp. 532-628 in Mammal species of the world. A taxonomic and geographic reference (D. E. Wilson and D. M. Reeder, eds.). The Johns Hopkins University Press. Baltimore, Maryland.

Yablokov, A. V. 1974. Variability of Mammals. Amerind Publishing Co. Pvt. Ltd., New Delhi, India, for the Smithsonian Institution and the National Science Foundation. Washington D.C.

YU, L., ET AL. 2011. On the phylogeny of Mustelidae subfamilies: analysis of seventeen nuclear non-coding loci and mitochondrial complete genomes. BMC Evolutionary Biology 11:92.

Zelditch, M. L., D. L. Swiderski, H. D. Sheets, And W. L. Fink. 2004. Geometric Morphometrics for Biologist. A Primer. Elsevier Academic Press. San Diego, California.

ZINK, R. M. 2004. The role of subspecies in obscuring avian biological diversity and misleading conservation policy. Proceedings: Biological Sciences 271:561-564.

Submitted 19 March 2020. Accepted 27 July 2020.

Associate Editor was Ricardo Moratelli.

Appendix I: List of SPEcimens Examined

Museo Argentino de Ciencias Naturales
"Bernardino Rivadavia" (MACN), Ciudad
Autónoma de Buenos Aires, Argentina

$21373 ; 25800$.

\section{American Museum of Natural History (AMNH), NEW YorK, USA}

389; 14861; 15471; 15473; 16938; 17554; 23483; 23484; 24444; $29597 ; 29598 ; 29832 ; 30202 ; 31445 ; 32065 ; 35943 ; 36507 ; 37366$; 37799; 37800; 38091; 38096; 40838; 42329; 46523; 48179; 61432; 71116; 71850; 71851; 71852; 74416; 74417; 74418; 76032; 76034; 76447; 76490; 76637; 76809; 76857; 76899; 78509; 79369; 79370; 92337; 92338; 92832; 92833; 95090; 95283; 95374; 123271; 128271; 
133952; 136282; 145948; 185325; 215134; 215135; 230838; 230839; $246962 ; 246963$.

\section{Field Museum of Natural History (FMNH), Chicago, USA}

$18763 ; 41211 ; 41607 ; 44332 ; 46221 ; 54642 ; 61873 ; 62076 ; 65794$; 65795 ; 66427; 66428; 68899; 68900; 68901; 68902; 69583; 69584; 69585; 69586; 70764; 70765; 78669; 78670; 87863; 88882; 88883; 88884; 88885; 90053; 90054; 92367; 94312; 94313; 94315; 95521.

\section{National Museum of Natural History (NMNH), WASHINGTON DC, USA}

14201; 35178; 48717; 51274; 100417; 104546; 104547; 132511; $149015 ; 171081 ; 202707 ; 241383 ; 244901 ; 255132 ; 256177$; $281466 ; 281467 ; 281468 ; 281469 ; 281470 ; 281472 ; 281473$; $281475 ; 290885 ; 297961 ; 307041 ; 310670 ; 310671 ; 310673$; $334554 ; 335772 ; 337292 ; 338976 ; 338977 ; 338978 ; 361035$; 361036 ; 361038; 362120; 362121; 362245; 362307; 364516; 406838; 442899; 443483; 443485; 443575; 443719; 460072; 461839; 499757; 544644. 